\title{
The Role of Military Schools in the Introduction of History Education to Turkey
}

\section{Research Article}

Erdal ASLAN ${ }^{1}$

${ }^{1}$ Dokuz Eylül University, Faculty of Education, Department of History Education, İzmir, Turkey, ORCID: 0000-0002-9267-9852

To cite this article: Aslan, E. (2021). The role of military schools in the introduction of history education to Turkey, International Online Journal of Educational Sciences, 13 (2), 536-555.

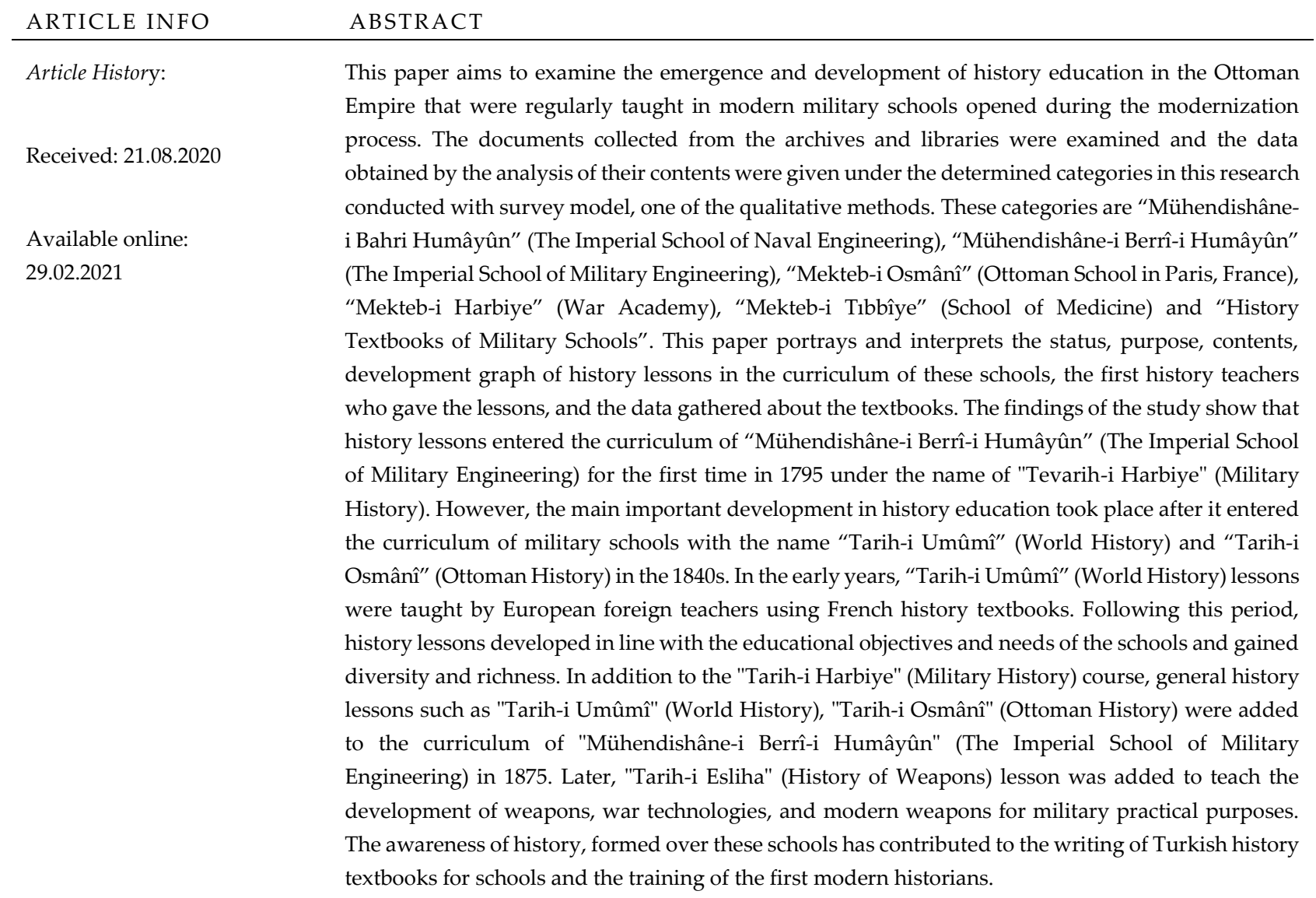

(C) 2021 IOJES. All rights reserved

Keywords:

History Education, Military Schools History Lessons, Ottoman Empire, Modernization and Education.

${ }^{1}$ Corresponding author's address: Dokuz Eylül University, Faculty of Education, Department of History Education

Telephone: +90-232-4204882

e-mail: erdal.aslan@deu.edu.com

DOI: https://doi.org/10.15345/iojes.2021.02.014 


\section{Introduction}

In spite of the fact that important initiatives gained momentum in the field of medicine, engineering and basic sciences after the middle of the 19th century in the modernization process of the Ottoman Empire, it was the first half of the 20th century that the developments in the field of social sciences reached the same speed. The imperial intelligentsia displayed a positive and enthusiastic approach to the technological innovations that would improve the tactical superiority and technical maneuverability of the army. However, they also showed a reactive and distant attitude towards the mental and intellectual formations that produced this technology. The ruling elites of the empire considered the schools in Paris and Vienna as the most modern educational institutions in Europe, thus the "military schools" were founded by modeling these schools. Pragmatic reasons enabled the transfer, development and expansion of the physical science and engineering sciences earlier. But the skeptical approach and distant attitude of the ruling elites of the empire led to a delayed and slower development in social sciences.

Despite this, modern military technical schools were the institutions that enabled the transfer of modern sciences and technologies emerging in Europe to the country, also introduced the intellectual structures, methods and tools of the societies that produce these technologies, and followed the developments of social sciences in Europe. Evaluating in terms of history education and historiography, this data was quite limited on the status of history lessons in traditional educational institutions of the empire until the opening of these institutions. Religions, prophets and the history of Islam were undoubtedly mentioned within the scope of the courses on the basic principles of Islam in the curriculums of madrasahs. History had also been taught to the children of the dynasty family and high-level government officials and had a very important place. However, it was not pleasant in terms of historiography including the fact that because history lessons were not regularly and systematically included in the curriculum of traditional educational institutions. The Palace employed or supported a few historians, but it was inadequate. While quite important developments had been made in the field of history in Europe since the 19th century, Ottoman historiography was far behind the level reached in the world of its time in terms of methods, aims, content and the understanding of history.

While history teaching and knowledge had an important place in the culture of the Ottoman elite, it was never a collective and systematic teaching subject. It always remained at an amateur level. Ottoman historiography of the period had a significant effect on the state of history teaching. Ottoman historiography could not go beyond "writing chronicles", which includes the transfer and explanation of the cases in general terms as a method. The causes of the events were not investigated, their results were not analyzed, and the connections that prepared the events were not examined. Therefore, historiographers could not go beyond being narrators, storytellers and descriptors; research and studies based on first-hand sources were underrated. Since teaching was not in question, very few didactic historical works were written. Until the Ahmet Cevdet Pasha period, there were almost no works that reflected historical events from different aspects and with a holistic understanding (Unat, 1964: 42).

Until the Tanzimat reform era, education for Ottoman Muslim societies was solely for the purpose of "the afterlife". Courses such as history, geography, calculation, biology, and profession and skill-building activities were not included in the school and Madrasa curriculums. With the reforms, semi-ethereal and semiearthly educational institutions started to be opened in addition to traditional and ethereal educational institutions. Advanced curriculums were applied in the institutions where non-Muslim Ottoman subjects and children of foreigners received education (Sakaoğlu, 1991: 25-26). Despite having a history of nearly four centuries, the Ottoman Empire fell into a period of dissolution and crumbling. This situation gradually gained momentum, making the Empire unable to cope even with the small structures under its rule. Everyone, from the emperors to the lowest staff, knew that a serious reform process had to be undertaken. Some of the reformists suggested that strengthening the traditional institutions of the empire and adapting them to the era 
was the best solution. Some other reformists argued that all the institutions and operations of the Ottoman Empire should be reshaped in accordance with the changing world conditions, and added that the powerful states of the period reached their current state by this way.

As a result, a modernization plan and strategy that tried to reconcile these two different ideas as much as possible was followed. In this direction, the projects of those who advocated the second option were put into practice as trial. While implementing these projects, they were executed by the most influential and pioneering staff of the traditional institutions that defended the first opinion. However, although this approach mitigated the reactions of traditional conservative people, the efficiency and effectiveness of the reform process decreased and the process was prolonged. The empire aimed at a growth and development focused on military success, so the first reform attempts were solely directed to the army. Therefore, the military field was the first to see the examples of the attempts to modernize education in the Ottoman Empire.

Although the structures, operations, effectiveness of military schools and the results obtained from all efforts are undoubtedly important, this study will focus only on the contributions of these institutions to history education and historiography. In Turkey, these schools were always the first to adopt developments regarding the modernization of the military and general education system, such as institutional arrangements, contemporary teaching methods, technologies, course materials, textbooks, formation of teachers and students, as well as modern insights in the social sciences and basic sciences. The introduction of the social sciences into Turkey, including history in particular, was through military training institutions that were established in order to ensure the modernization of the Ottoman Army and to raise technical staff that will have comprehensive knowledge of modern technology.

The first two examples were "Mühendishane" (Engineering School) and "Mekteb-i Tibbiye" (School of Medicine). These schools were the first to teach the courses that included worldly subjects related to human and society at primary, secondary and higher education levels. History lessons were also included in their curriculum, while they did not have a very important function, and the prominence of history was not yet sufficiently understood. In the Ottoman Empire, the first educational institution to include history lessons in the modern sense in its curriculum was "Mühendishâne-i Bahri Humâyûn" (The Imperial School of Naval Engineering), followed by "Mühendishâne-i Berrî-i Humâyûn" (The Imperial School of Military Engineering), "Mekteb-i Osmânî" (Ottoman School in Paris, France), "Mekteb-i Ulûm-1 Harbiye" (School of Military Sciences), and "Mekteb-i Tibbîye-i Şahâne" (The Imperial School of Medicine) which was opened to compensate the physician needs of the army.

History education, began for the first time in modern military schools as a regular and scheduled course, gained diversity and continuity with "Mahrec-i Aklâm" which was a school to train civil servants (clerks) required by the state bureaucracy, and its later replacement "Mekteb-i Mülkiye-i Şahane" (Imperial School of the Civil Services) which was established and restructured by modeling the School of Political Science in Paris. History education was included in the curriculum of "Dârülmuallimîn-i Rüşdiye" (Collage of Rüşdiye Teachers), which was opened to enlist teachers for "Mekâtib-i Rüşdiye". Despite the history education did not gain an independent field identity with it, it had been an important step towards making history education widespread at the primary and secondary level education while obtaining a wider teaching staff. In the Ottoman Empire, the foundations of history education were laid in military schools, it developed and became widespread through modern civil schools, leading to the training of the first professional historians and the preparation of textbooks. This paper investigates the role and contribution of modern military schools in the introduction of history education to the Ottoman Empire. Besides, it would be useful to remind the historical background and the opening process of these schools briefly before mentioning the role of military schools in the introduction of Turkey to history education. 


\section{Reform in Military Education and Opening of Modern Military Schools}

The first attempt in the field of modernization of military education in the Ottoman Empire started with the "humbarahane" (Artilery School) in 1727 with the suggestion of İbrahim Müteferrika (Dölen, 1985: 511). Grand Vizier Damat İbrahim Pasha directed this initiative using local officers in the period of Sultan II. Ahmet. A military unit was formed by selecting 300 people among the members of the "Bostancı Ocağı" (the place where the soldiers guarding the sultan were trained) in Üsküdar, and a march and weapon training was carried out in Haydarpaşa Meadow according to this new method. However, the school was not developed, and all of the soldiers trained here were killed during the Patrona Halil Rebellion in 1730. Thus, the first attempt to modernize the Ottoman military training was left unfinished before it could be completed (Ergin, 1977: 59; Cihan, 2007: 38). However, the dramatic ending of this initiative led to the spread of the idea that the Ottoman army needed a radical and permanent reform.

It was decided to open a school called "Humbarahane and Hendesehâne" (Artillery and Engineering School) (Koçer, 1991: 23) in a barracks that was reconstructed in the "Ayazma Palace" (Baysun, 1999: 983; Kazancigil, 2007: 227) next to the old asylum building in Toptaşı in Üsküdar in 1734 (Adıvar, 1991: 182; Uzunçarş1lı, 1988a: 324) for the non-commissioned officer staff of the artillery class trained with technical knowledge. The foundation of this school was approved and reorganized by a decree dated 1735, and a total of 600 grenadiers were gathered for this school (Kazancıgil, 1007: 227). The appropriate ones among Boğaziçi Bostancı and Haseki individuals, who seemed gentler compared to the Janissaries, were selected and enrolled in this school (Ergin; 1977: 62; Erendil, 1988: 99; Uzunçarş1l, 1988-b: 117-118). The school, which formed the core of the military and civil engineering schools to be opened later in the Ottoman Empire, was also the first educational institution where positive sciences were taught (Unat, 1967: 14). It was named as "Engineering School" because of the mathematical courses given under the name of "Hendese" (Ministry of National Defense, 2000: 241). Europeans named this school as Corps des Mathematiciens (The Class of Mathematicians) since it was focused on math and geometry (Adivar, 1991: 183). When Sait Pasha, France Ambassador of the Ottoman, was returning to Istanbul in 1742, he brought 22 French artillery to Istanbul to help Ahmet Pasha (Kafadar, 1997: 74). Following the death of Grenadier Ahmet Pasha in 1747, his stand-in son and subordinate Süleyman Bey from Milan was appointed as the head of the grenadiers, but after his death, this unit was dismantled (Uzunçarşıll, 1988-1: 325). Humbarahane (Artillery School), which was opened by Damat İbrahim Pasha (1727), focused on artillery training, while Humbarahane-i Hendeshâne (1734), focused on geometry training. Like its counterparts in Europe, theoretical and more practical war preparation training were given and it was designed as a model for the reorganization of the Ottoman army.

However, Humbaracı Ocă̆ı (Artillery Unit) and Humbarahane-i Hendesehâne did not last very long. Some artillery officers did not like the new drills. The school was disbanded and closed for fear of rebellion (Berkes, undated: 68; Mahmut Esat, 1310: 6). While studies in Humbarahâne-i Hendesehâne were conducted in secret, the European-style walking drills and technical training of students gained interest over time. It was heard that the janissaries, who saw this situation as a danger to their status and existence, made preparations for a bloody riot. Thereupon, the school was closed and its students were distributed in 1749 (Koçer, 1991: 23; Ergin, 1977: 62). The main purpose of the training in Humbaracı Ocağı (Artillery Unit) was to train soldiers who could successfully use new weapons and war techniques, and to introduce the developing weapon technology in Europe, rather than to provide military engineering education as in Europe of the period (Kaçar, 1999: 481). Despite failing to achieve the expected goal, the opening of this school was the turning point in the history of Ottoman education and science in terms of the transfer of modern western science and education system to the Empire. The courses included in the curriculum were a breaking point in the traditional education system of the empire with the teaching methods and tools used in the courses. 
During the reign of III. Mustafa, the Grand Vizier Koca Ragip Pasha took action to reopen this school in 1759. He gathered old students who survived or children of deceased ones, started training them again in a large building in the area of Karaağaç in the Golden Horn. Until the accession of III. Selim, the education continued here in a dull way (Adıvar, 1991: 203; Ergin, 1977: 62). The poet Grand Vizier Ragip Pasha believed that the old order would be completely lost while making reforms, therefore he neglected the modernization of the army. The most important reason for this was that he lost all hope on this subject or he believed that it would have terrible consequences (Berkes, undated: 68). Thus, another attempt failed.

Britain modernized, supported and managed the Russian Navy that nobody believed that they could enter the Mediterranean Sea in any way. So, it was a big surprise when the navy reached the Aegean Sea during 1768-1774 Ottoman-Russian War. The Mediterranean domination, all islands and the security of the Dardanelles were at risk after the Ottoman navy was burnt down by Russian ships in the Çeşme Port in 1770 with a sudden raid (Uzunçarş1l1, 1988c). Thereupon, Grand Admiral Hasan Pasha of Algiers was assigned to strengthen the Ottoman navy, and Baron de Tott in Istanbul was assigned to prevent a possible attack by the Russian Navy, which was moving towards Gallipoli strait, and to fortify the defense line.

Thanks to the new bastions built by Baron De Tott on the Asian and European sides of the Gallipoli strait, Russian Admiral Alexis Orlof withdrew because he thought that they could not exit from the Gallipoli strait if they entered it (Kaçar, 1994: 38; Türkcan, 2009: 353). After the failed attempts of the Russians to cross the Gallipoli strait, Baron de Tott returned to Istanbul and took part in the arrangement of the Bosporus castles in Istanbul, the establishment of the bastions, the repair of the boat bridge system used in the army, and the redetermination of the shape of the gun carriages (Uzunçarşı1l, 1988-1 : 324, 480).

In 1772, Baron de Tott built an artillery foundry and established an artillery school in Hasköy, located next to the shipyard in the Golden Horn, in order to rearrange and train the Ottoman artillery class. Shortterm courses were given to the existing artillery here. Although it was appreciated by Sultan III. Mustafa who personally followed the shooting drills, the work of Baron de Tott, particularly his effective works in the field of artillery, did not last very long. Due to the inability to abandon the old artillery traditions, the difficulties in adopting new methods, the lack of sufficient staff in the school, and Tott's aim to manage the school alone by opposing the new teachers, this school was abandoned in 1773 despite the success of the artillery who attended the courses, and another artillery force consisting of militia was formed (Beydilli, 1995; Kaçar, 1994: 46; Kaçar, 1998: 77-78). When it was realized that the old habits of the artillery could not be abandoned by giving courses, Sultan Mustafa III established the "Sürat Topçuları Ocă̆ı" (Field Artillery Unit) on 17 January 1774 with an edict, and appointed French Artillery Sergeant Antoine Charles Aubert as an educator. Yet, he died four days after the edict. The purpose of the establishment of the school was to train artillerymen drilling with European methods (Uzunçarş1l1, 1988-1: 481; Uzunçarş11, 1988-2: 67).

Following the defeat of Çeşme, on the one hand, land troops were rehabilitated through the "Artillery School", on the other hand, action was taken to renew the navy and train the seafarers working in the navy with modern scientific methods as in Europe. Upon the request of Grand Admiral Hasan Pasha of Algiers, with the advice and help of Baron de Tott, a class called "Hendese Room" was opened in the Golden Horn on April 29, 1775. Grand Admiral Hasan Pasha of Algiers was appointed as the first teacher of this school, which was accepted as the core and the beginning of Mühendishâne-i Bahr-i Humâyûn (The Imperial School of Naval Engineering). However, after he was promoted to the Second Admiral position, Seyyid Osman Efendi was appointed with a test (Uzunçarş11, 1988-a: 482; Ergin, 1977: 316). The students who will receive education here had been selected among the surviving ones who were previously trained in Bonöval's "Humbarahane-i Hendesehâne". The aim of this school, which started its education with ten people, was to meet the navy's need for experts with mathematics, geography and technical understanding. Due to the severe need for the improvement of the Ottoman Navy, this school provided navy training unlike the previous Hendeshâne. 
There were two other teachers apart from Hasan Pasha of Algiers and Baron de Tott in the school; Kermnorvan and Kompel Mustafa. Kermnorvan was a French man, and the nationality of Kompel Mustafa was British, but he was originally from Scotland (Uzunçarş1l1, 1988-1: 482).

Hendesehâne, as a school where "Mathematics" and "Engineering" courses were taught for the first time in the Ottoman Empire by using western sources and new methods, became the core of the Imperial engineering schools. Upon the opening of the school, the books and tools related to mathematics found in the Palace and other places were asked to be sent to Hendeshâne, and the textbooks and tools required for the courses in the curriculum were brought from Paris (Kaçar, 1998: 7). Hendeshâne started to be called "mühendishane" (Engineering School) since 1781. "Hendeshâne" did not meet the needs because of its small size, it moved to a new three-room engineering building built near the current Camialt1, next to the shipyard dungeon in 1782, during the time of Halil Hamid Pasha's grand vizier and Ata Bey's shipyard assurance. Since its establishment in 1776, more importance was given to the lessons of calculation, geography and mapping. Thus, Hendesehâne's education area expanded with its transition to the new building. Lessons given in French by French teachers were translated into Turkish by Kirkor and Mihran Efendi and given to students. Tuquet's book of tactics was translated into Turkish under the title of "Usul-ül-maarif fi veçh-i tasnif-i sefain-i donanma" and was published in the French Embassy Printing House in 1782. (Uzunçarş1lı, 1988-c: 507-508). In November 1784, on the orders of Grand Vizier Halil Hamid Pasha, shipyard clerks and other interested parties were allowed to attend the lectures in "Mühendishane" (Engineering School) for two days a week to learn "Hendese". For these, a supplementary allowance per student was allocated to the school budget. With this application, students from outside were also started to be accepted to "Mühendishane" (Engineering School) (Kaçar, 1999: 682).

The applied engineering education was started over a fortification model they made in the garden of Aynalıkavak Palace in order to form the basis of the "Kara Mühendishânesi" (School of Engineering), which was established in Mühendishâne (Engineering School) in 1784 (Kaçar, 1999: 682; Uzunçarş1l, 1988-c: 507-508). With the new regulations, it was opened in 1795 under the name of "Mühendishâne-i Bahri Humâyûn" (The Imperial School of Naval Engineering) to train the engineers needed for the armies of the empire. "Mühendishâne-i Bahri Humâyûn" (The Imperial School of Naval Engineering) and "Mühendishâne-i Berrî-i Humâyûn" (The Imperial School of Military Engineering) could be considered as the gateway of modern mathematics and science education in Turkey. The development and structuring of these schools in the historical process enabled the courses taught in these schools to gain variety and to enhance their content. History was one of the lessons that were added to the curriculum afterwards with the regulations made in modern military schools. Examining the introduction of the curriculum of these schools to history lessons and their development is tremendously essential in terms of making a sound assessment of the history of history education.

\section{Purpose and Importance of the Research}

This paper aims to examine the emergence of history lessons that were started to be taught in the modern military schools opened during the modernization process for the first time in the Ottoman Empire. The state of history education in the Ottoman Empire has been the subject of many studies and research (Ata, 2017; Bülbül, 2019; Demircioğlu, 2008; Demircioğlu, 2012; Erkan, 2017; Nakıp, 2006; Özdemir, 2019; Özteke, 2006; Şengül, 2006; Tunçay, 1977; Türk, 2006; Yıldız, 2006). However, the studies on this subject focused completely on the period after "Maarif-i Umûmîye Nizamnâmesi (Regulation of Public Education)" (The law stipulated by the Ottoman State to establish a secondary education institution) except for one (Gökçen, 2020) nearly all of the relevant investigations have focused on processes with a richer source material, such as the reign of Abdulhamid II and the Second Constitutional Monarchy. However, apart from the fact that there are no publications about the first periods of the curriculums of modern military schools in the Ottoman Empire, it 
is far from forming a general opinion since the evaluations and interpretations regarding the history education of the period were very limited. Researchers are expected to reveal the state of history education in military schools, which were the first modern schools established in the Ottoman Empire, to clarify its development and to form the basis for future research.

\section{Methodology}

This paper grounded on the qualitative approach, and used the survey model in order to determine the place of a past or present situation within its own conditions (Karasar, 2007). The survey model, which is the main method used in historical research, is based on the interpretation of the data obtained from the analysis of the contents of the documents containing direct or indirect data on a subject that is worthy of examination, under the categories determined by the researchers (Yıldırım \& Şimşek, 2006: 187).

\section{Data Collection and Its Analysis}

The data of the study were obtained with document analysis method from historical sources available in libraries, written with Ottoman and Latin alphabets, which were about the modernization of education in the Empire period, and from the few studies based on these sources. The data were obtained by scanning comprehensively archives and libraries such as State Archives of the Prime Ministry of the Republic of Turkey, Izmir National Library, Atatürk Library in Taksim, Catalog of Seyfettin Özege at Ataturk University. The research was carried out based on the examination of the relevant documents, and the data obtained were interpreted by analyzing the content. The content of the documents included in the study was analyzed following the stages of "choosing a sample from the data, developing a category, determining the unit of analysis" suggested by Yıldırım \& Şimşek (2013). The data has been categorized as the modern military schools "Mühendishâne-i Bahri Humâyûn" (The Imperial School of Naval Engineering), "Mühendishâne-i Berrî-i Humâyûn" (The Imperial School of Military Engineering), "Mekteb-i Osmânî" (The School of Ottoman in Paris, France), "Mekteb-i Harbiye" (War Academy), "Mekteb-i Tibbîye" (Medical School), and "History Textbooks of Military Schools". Under these categories, data about the teachers and the books have been compiled and interpreted according to their status, names, subjects, entry dates in the curriculum.

\section{Findings and Interpretation}

The findings obtained as a result of the description and interpretation of the data obtained by the analysis of the contents of the documents examined within the scope of the research showed that the entry of history lessons into the curriculum in the Ottoman Empire coincided with the opening of modern military schools and their development progressed in parallel.

\section{History Education in Modern Military Education Institutions}

From the first years of education to the formation of modern primary and secondary education institutions, schools such as "Hendesehâne", "Mekteb-i Tibbiye" (School of Medicine), "Mühendishâne-i Bahri Humâyûn" (The Imperial School of Naval Engineering), "Mühendishâne-i Berrî-i Humâyûn" (The Imperial School of Military Engineering), and "Mekteb-i Harbiye" (War Academy) aimed to meet the requirements of the military. Different practices that changed and developed over time was applied in order to prepare the students selected for vocational education in these schools. The new and modern educational institutions with very limited opportunities at the beginning, were established by modeling the institutions that were considered to be the newest and most qualified of the period, generally in France. When these schools were first established, experts invited from different countries generally worked as trainers and administrators. Later, the local staff trained by them took their places. The first years of the "Tibbiye" (School of Medicine), and "Mühendishâne" (Engineering School) were reserved for the preparatory education in order to cultivate the students selected for these schools for military technical education and to make up for their deficiencies. 
In the following periods, preparatory classes under the name of "i'dâdî" were opened independently from their vocational education in order to bring students to the level of military vocational training. The curriculum of the one-class Military Preparatory was quite simple in 1847: Arabic, Farsi, History, Geography, Calculation, Hendese (geometry), and a bit of Algebra (Ergün \& Duman, 2014).

These classes, which provided education under the name of "I'dâdî" (Preparatory) in military schools, had been restructured in the light of the experiences gained over time and transformed into "Mekteb-i I'dâdî" (Preparatory School) by having an institutional identity within each school and they became the basis for the secondary education institutions to be opened in the Ottoman Empire in the later periods. All preparatory classes and schools within military training institutions were united under one roof to increase efficiency. During these processes, basic sciences (physics, chemistry, botany, zoology, mineralogy) are included in the curriculum at the very beginning. Social sciences such as history, literature, philosophy, ethics are also included in the curriculum after a while, except geography (geography was in the curriculum since the first periods of schools). So, the courses had become richer in content and number over time. (Aslan, 2016). The courses, curriculum and textbooks taught in both preparatory classes and schools were prepared in accordance with their examples in Europe. Military schools were established to train experts who knew the science and technological knowledge developed in Europe by transferring them to the Ottoman military technical staff. At the same time, they played a pioneering role by allowing the understanding of social sciences, especially history, developed in Europe to enter the Ottoman Empire. These institutions developed over time and became secondary education institutions. Hence, the courses in the curriculum of these schools were also the first examples in the Ottoman Empire, that were developed in accordance with the modern understanding in 18th century Europe. This situation was valid for all courses included in the curriculum of these schools. So, modern military schools became the gateways of a new understanding of science to the Ottoman Empire in every field.

The first modern curriculum and textbooks progressed over time through these schools, and the first teachers and first modern scientists who taught these courses were trained in these schools. Although a more rapid change was observed in terms of basic sciences, especially mathematics, physics, chemistry, botany, zoology, the development of social sciences was not very different. Before Mekteb-i Mülkîye-i Şahane (School of Civil Cervices) was established, the first courses, books and insights reflecting the new approach to the social sciences, especially to history and geography, emerged and developed in Europe, entered Turkey for the first time through preparatory classes of the military schools mentioned before, and gained prevalence and legitimacy after they were embraced there.

\section{History Education in Engineering Schools}

Considering its place in the education taught in "Mühendishâne-i Bahri Humâyûn" (The Imperial School of Naval Engineering) and "Mühendishâne-i Berrî-i Humâyûn" (The Imperial School of Military Engineering), it is important to note that the history education developed mostly in "Mühendishâne-i Berrî-i Humâyûn" (The Imperial School of Military Engineering). The history education of this school was very limited. Because the main purpose of this school was to train officers and technicians with geography and mathematics knowledge, who could draw maps, and know the geography of the seas and lands very well, and focus on closing the deficit of the army in these areas. For this reason, even if geography occupied a very important place in "Mühendishâne-i Berrî-i Humâyûn" (The Imperial School of Military Engineering) and its preceding Hendesehâne curriculum, information on the status of history lessons is very limited.

The books registered in the library of the school are the proof of the fact that the textbooks used in geography lessons in "Mühendishâne-i Bahri Humâyûn" (The Imperial School of Naval Engineering) included European naval history as well as Ottoman naval history (Toderini, 2018). The lists of the history books given by Toderini does not include any "Tarih-i Umûmî" (World History) or "Tarih-i Osmânî" (Ottoman History) book in the library of Topkapı Palace and in this school. The fact that all history books consisted of 
traditional Ottoman historiography makes it very unlikely to have an independent history course among the courses taught in "Mühendishâne-i Bahri Humâyûn" (The Imperial School of Naval Engineering). Information on history lessons in this school was dated after the 1840s. However, if the fact that history lessons started to be given in the preparatory classes of other military schools after the 1840s and the relationship between these schools are taken into consideration, it can be argued that history education entered the curriculum of "Mühendishâne-i Bahri Humâyûn" and gained continuity at the same time with other schools.

Table 1. History Courses in Mühendishâne-i Bahri Humâyûn (The Imperial School of Naval Engineering)

\begin{tabular}{lll}
\hline Course & Class & Starting Date \\
\hline The History of Wars & Second Class & 1795 \\
History & Preparatory Class & 1847 \\
The History of Weapons & Engineer Corps $3^{\text {rd }}$ Year & 1878 \\
The History of Warcraft & Field Artillery $4^{\text {th }}$ Year & 1878 \\
World History & Preparatory $2^{\text {nd }}$ and $3^{\text {rd }}$ years & 1878 \\
The Ottoman History & Preparatory $1^{\text {st }}$ and $3^{\text {rd }}$ years & 1878 \\
\hline
\end{tabular}

Courses on social sciences such as modern science and mathematics, especially history, entered the educational institutions of the Ottoman Empire for the first time with the curriculum of "Mühendishâne-i Berrî-i Humâyûn" (The Imperial School of Military Engineering) dated 1795. "Geography" was among the courses taught in "sinif-1 salis" (the third class) in this curriculum. "Geography" and "Tevarih-i Harbiye" (History of Wars) courses were among the courses taught in the "sinif-1 sani" (the second class). The aforementioned courses were preserved in the 1805 curriculum of the school without any change (Mehmed Esad, 1312: 15-16; Erdem, 1986: 12; Ergin, 1977: 327). With an arrangement made in 1847, the structure of "Mühendishâne-i Berrî-i Humâyûn" (The Imperial School of Military Engineering) was reorganized and divided into "artillery" and "architect" schools, and "i'dâdîyye" (Preparatory Class) ramined within the "Mühendishâne" (Engineering School). "Arabic, Farsi, History, Geography, Arithmetic, Geometry and Algebra" courses were taught in the "i'dâdiyye" class (Preparatory Class) covering the first year of education. Students who successfully completed these courses were assigned to one of the artillery or architect classes in the second year. After completing their education there, they were assigned to units needed in the army (Mehmed Esad, 1312: 99-100; Erdem, 1986: 79). In 1865, Mr. Blum gave lectures on "History of Wars" along with military defense courses, "Geography" was taught by Mr. Bon who also gave "Architecture" lessons (Uluçay, 1958: 78). With an arrangement, "Mühendishâne İ'dâdî" (Preparatory Engineering School) was moved to Galatasaray, and the "Mekteb-i Bahriye" (Naval Military School), "Mekteb-i Tibbiye" (Medical School) and "Mekteb-i Harbiye" (War Academy) were restructured in accordance with the examples in Europe. They were united under the name of “İ'dâdi-i Umûmî” (General High School) (Mehmed Esad, 1213: 123; Erdem, 1986: 98).

When "Mühendishâne" (Engineering School) was re-established and started education in 1878, "History of Weapons" and "Military Geography" courses were included in the $3^{\text {rd }}$ grade of the "Military Defense Unit" (Mehmed Esad, 1213: 139-141; Erdem, 1986: 113-114). "Art of War" was added to the curriculum of $4^{\text {th }}$ grade of "Artillery Unit", and "History of Wars" was added to the $5^{\text {th }}$ year's curriculum (Mehmed Esad, 1213: 147; Erdem, 1986: 118). "Ottoman History" and "world History" were among the courses of the third year in the curriculum of "Mühendishâne-i Berri Hümâyun İ'dâdiyye" (The Imperial School of Military Engineering), "Ottoman History" in the second year, "World History" and "Geography of Ottoman" were in the first-year courses. It is noteworthy that there are "Târîh-i Umûmî" and "Geography-yı Osmâniyye" courses (Mehmed Esad, 1213: 150-151; Erdem, 1986: 120-121). "Hendese-i Mülkiye Mekteb-i" (Engineering School for Civil Services), which was opened in 1884. The duration of the education was determined as seven years, and in the curriculum, "World History" and "Geography of Ottoman" were included in the first year courses, and "Ottoman History" was included in the second year courses (Mehmed Esad, 1213: 156-157; Erdem, 1986: 126; 
Uluçay, 1958: 196; Gökçen, 2020: 114-115). In the light of all this information, it is understood that the history lessons taught in Engineering Centers were given with a content and understanding that can correspond to today's secondary school or high school level. On the other hand, "History of Weapons" was taught in the $3^{\text {rd }}$ grade of the "Defense Unit", "Art of War" in the $4^{\text {th }}$ grade of "Artillery Unit", "History of Wars" in the $5^{\text {th }}$ year to selected students. These courses have been taught as history lessons for military purposes in order to provide historical support for the development of military knowledge and skills for professional purposes. The "History of War" courses were taught as history lessons for military purposes in order to provide historical support for the development of military knowledge and skills for professional purposes.

The findings show that the French "Tarih-i Umûmî" (World History) textbooks were used in the first periods of "Mühendishane" (Engineering School). Especially, the absence of a published textbook for history lessons in the Engineering School Printing House supports this situation. Only one historical book was published in the Engineering School Printing House. Ahmet Vasıf Efendi's book named Vekây'-i nüvis, which has 2 volumes (Mehâsinü'l-âsâr and hak-âikü'l -âhbâr) covering the years of 1752-1774, published in 1804 (Beydilli, 1995: 256). When the book was published, Ottoman History courses were given in Medicine School but not in Engineering School, so it is a weak possibility of it being used as a textbook.

In the early years of Mühendishâne (Engineering School), "History of Wars" lessons were given by Blum Pasha, "History of Weapons" lessons by Captain Schmit, and the "World History" lessons by Mr. Bonn, who also gave geography lessons (Mehmed Esat, 1213:375). Miralay Salih Efendi, who also taught Arabic and Persian in the following years, was appointed for the history lessons. Salih Efendi started to teach "World History" and "Ottoman History" in Darüşşafaka and Menşe-i Muallimin (Military Teachers Teaching School) in 1876, and he was assigned to teach history courses in "Mühendishâne" (Engineering School) in 1893 (Mehmed Esad, 1312: 359). -362).

\section{History Education in "Mekteb-i Harbiye" (War Academy)}

"Mekteb-i Harbiye" (War Academy) was another attempt of the Ottoman Empire to modernize the army. The modernization of the army was initiated by Mahmut II, and new institutions were frequently established in the following periods, revisions were made for the improvement of these institutions, effective arrangements were continued as needed in the process, and sometimes new institutions were established. The aim of all these attempts was to train military officers who were able to master the modern war strategies of the army, follow and adapt new war technologies rapidly developing in Europe. The aim was to have welltrained technical military officers who could transfer the developing military technologies and war strategies to the Ottoman Empire, and produce them. In order for the system to function properly and to provide the expected benefits, great emphasis has been placed on the establishment of a merit-based system in the management of the army and promotions to higher positions. Despite all these efforts, the expected results were not fully achieved and the army's need for officers could not be met.

"Mekteb-i Harbiye" (War Academy) was established in 1834 as a reform initiative in order to meet the officer needs of the Ottoman Army. In the first months of its establishment, it was called by various names such as Ekol Militer, Mekteb-i Ulûm-u Harbiye, Mekteb-i Fünûn-u Harbiye, Asakir-i Hassa-i Şahane, Mektebi Harbiye-i Mansure ve Mekteb-i Hassa (School of Military Sciences). Eight months later (July 1, 1835), it was named "Mekteb-i Harbiye" (War Academy) after Mahmut II's inspection (Gök, 2005: 81). The school had difficulties in finding students due to negative propaganda. So, they started to train orphans gathered from streets. Since these children did not even know how to read or write, preparatory classes were set up because basic education was needed in the first place. Due to the facts that the preparatory education took a long time and the military courses in the curriculum did not have the required technical equipment and infrastructure, educational activities were inadequate until 1837. With a decree issued in 1837, "Ministry of Education" was established to redefine the management and educational processes and student admission to the school. 
Providing more efficient education they categorized the subjects of the education under 15 different headings with this regulation. It is remarkable that "Politics of National and International Affairs" was among the subjects, although there is no history course among the courses given for officer training (Gök, 2005: 98-99).

Table 2. History Courses in Mekteb-i Harbiye (War Academy) and their starting dates

\begin{tabular}{lll}
\hline Course & Class & Starting Date \\
\hline History of Infantry & Second Class & 1845 \\
History and Art of War & Fourth Class & 1845 \\
World History & War Academy & 1850 \\
Short History of Weapons & Ottoman Military College & 1850 \\
History of Wars in French & Ottoman Military College & 1850 \\
World History & Ottoman Military College & 1850 \\
History of Ottoman Military & War Academy & 1867 \\
\hline
\end{tabular}

With the declaration of the Tanzimat, reforms aimed at improving the education in "Mekteb-i Harbiye" (War Academy) gained momentum. In 1840, a teacher was invited from France to strengthen French education in addition to the Arabic and Persian lessons in the curriculum. Emin Pasha (1841-1846) was appointed as the Commander of the school in 1841 so that the school could provide a better education. Emin Pasha, a commander trained in Europe, focused on science lessons to toughen the positive sciences since the students had "inadequate knowledge of science" (Mehmet Esat, 1912: 67). For this reason, Emin Pasha brought teachers from France and Prussia in order to bring the educational activities to the same level with the schools in Europe (Mehmet Esat, 1912: 43-45; Gök, 2005: 115-116). However, the main arrangements for "Mekteb-i Harbiye" (War Academy) were made in 1845. Some developments were made to transform the school into an institution that produces knowledge of war. Military education was arranged as a hierarchical system and the order of "İ'dâdîi Harbiye" (Preparatory War Academy) and "Erkan'i Harbiye" (Ottoman Military College) was established. Later on, the military junior highs were added that constitute the lowest level of the hierarchy (Gök, 2005: 114-116). However, the expected attainment from all these regulations could not be achieved, since there were no graduates in 1849 due to failure in exams and inadequacies in education. Only three students could graduate in 1850 (Mehmet Esat, 1912: 68). The curriculums applied between 1845 and 1867 included "History of Infantry" in Second Class, and "History and Art of War" in Forth Class (Kurtcephe \& Balcıŏlu, 1991: 131). This result necessitated a comprehensive reform in the institutional structure and curriculum of the "Mektebi Harbiye" (War Academy).

Along with the first attempts to train teachers except military, the first endeavor to train history teachers occurred in Mekteb-i Harbiye" (War Academy). In 1864, a department under the name of "Muavin Sinif" (Subsidiary Class) was opened in Istanbul in order to train teachers for other general culture courses other than military-related vocational courses in military centers in Mekteb-i Harbiye" (War Academy). Students were recruited to the department among the graduates of the military who have teaching skills in order to encounter math and art teacher needs. Military teachers who graduated from 3-year "Muavin Sinif" (Subsidiary Class) started to work with the rank of captain. The school produced graduates in 1868 and 1869 (Unat, 1964: 36,66). It was an important experience training teacher as well as meeting the teacher needs of military schools. In 1850, "World History" was included in the curriculum of "Mekteb-i Harbiye" (War Academy) as well as other schools (Ergün \& Duman, 2014). in Erkan-1 Harbiye (Ottoman Military College), "Short History of Weapons" and "History of War in French" courses were given, and Mustafa Şevket Pasha's History of War textbook was taught.

Upon the death of Galip Pasha in 1875, Süleyman Hüsnü Pasha, known as the hero of Shipka, was appointed as the commander of "Mekteb-i Harbiye" (War Academy). Süleyman Hüsnü Pasha, who was promoted to the rank of Mirliva (Brigadier General) and was appointed as the head of the school, also gave 
the history lessons in the curriculum of this school. After Süleyman Pasha was appointed as the commander of the school, he made some arrangements that led to significant changes in the institutional structure and education system of the military schools within the empire. He reorganized the structure, curriculum and education system of the school by using the curriculum of the military schools of the European countries of the period (Unat, 1964: 66).

Süleyman Hüsnü Pasha made arrangements related to the structure and curriculum. They were based on French St. Cry Military School, known as the first modern military school in Europe (Gök, 2005: 146). According to this curriculum, the training period of the Military School was determined as three years for Rüştiye (), and four years for the I'dâdîye () class. The infantry and cavalry would receive three years of training together in the first two classes, and in separate classes as artillery and engineers in the third class. One of the most important modernizations Süleyman Hüsnü Pasha put into practice was to launch a private and higher level of teaching school under the name of "Menşe-i Muallimin" (Teachers College) in "Mekteb-i Harbiye" (War Academy) in 1876 to train civilian teachers in accordance with the curriculum and objectives of the military schools that the Ottoman Empire sought to advance in big cities (Unat, 1964: 66). "Menşe-i Muallimin" (Teachers College) was organized as preparatory classes with a five-year education period, and thereafter higher classes with a two-year education period (Unat, 1964: 36; Ergin, 1977: 715). I'dâdî (Preparatory Classes) and military preparatory classes had the same curriculum. Foreign languages, especially French, were great focusing points in the curriculum. İ'dâdî (Preparatory Classes) consisted of five grades. Those who graduated from the fourth grade were divided into two branches, "literature" and "science", in the fifth grade. Those who completed İ'dâdî (Preparatory Classes) of "Menşe-i Muallimin" (Teachers College) had to take a proficiency exam so as to continue in the higher classes. Students who graduated from civil preparatory classes would also take the proficiency exam and get accepted to the higher classes (Unat, 1964: 36; Ergin, 1977: 516).

The higher classes of "Menşe-i Muallimin" (Teachers College) consisted of 11 branches, with the duration of education varying between two and four years. Major departments and training periods were determined as follows:

Classes with 2 years of education: Topography Class, Turkish Literature Class, History Class, Geography Class, Basic Math Class, First Painting Class, Second Painting Class.

Classes with 3 years of education: Applied Basic Math Class, Higher Math Class;

Classes with 4 years of education: Applied Higher Math Class, Science Class However, what matters here is the history class.

The curriculum of the History Class with two years of education: The courses were "General Geography, Natural Geography, First Age, Middle Age, Recent Ages, Contemporary History, History of Ottoman State, Statistics, History of Geography, Foreign Language" (Ergin, 1977: 716-718).

This school was only able to open preparatory classes despite the fact that it was designed to teach at the university level. It had no students due to the war in 1877 and closed due to the Abdulhamit's suggestion that civilian teachers would be harmful to the army and its discipline (Unat, 1964: 36). The school was organized and expected to offer a higher education than both Dâr-ul-fünun and Dâr-ul-Muallimîn, which was the only teacher training institution of the time and $90 \%$ of its students came from madrasahs (Ergin, 1977: 718). This was the first and the foremost initiative to train branch teachers in the modernization period of Turkey. It had a better and more comprehensive curriculum than the schools opened in the following years; but it remained inconclusive and could not reach its goal. However, it had a very important historical quality in terms of including the curriculum of the courses planned to be given in the education of the teachers. Considering the training of history teachers, the history subjects and courses planned to be taught had a more wide-ranging content compared to the historiography understanding of the period. Although it could not be 
put into practice, this curriculum formed a model for of secondary education institutions and the education plans of the Mekteb-i Mülkiye (School of the Civil Services).

\section{Students Sent to Europe, Mekteb-i Osmânî and History Education}

Egyptian Governor Mehmet Ali Pasha was trying to send students to Europe since 1815 in order to train military and civilian staff who could plan and perform the reform efforts. He drew the attention of the Ottoman rulers. Egypt made a great progress in terms of modernization at that time and the reports of the students and ambassadors that the Ottomans sent to Europe for educational purposes caused the Ottoman Empire to follow this path. The first student was sent to France in 1820-21 on behalf of the Ottoman Empire. This student was Ali Riza Pasha who studied artillery and bulwark in Askeri İdadiye Mektebi (Preparatory Military School) for 9 years, graduated as a captain, was promoted to major when he returned to Turkey and became one of governors and marshals (Fat, 2004: 4). Later, with the initiative of the secretary and captain of Mahmut II, Hüsrev Pasha, another student who was sent to London in 1832-33, but after that he was transferred to Paris and studied at Ecole Egyptienne. In the following years, the Ottomans sent more students to Europe. It became increasingly popular and evolved into a state policy. Year by year, there had been a significant increase in the number of students sent to European countries such as France, England, Austria, Prussia (later Germany), Belgium on behalf of Engineering, Officer, Medical, Political Science Schools and other institutions (Şişman, 2004; Erdoğan, 2016).

A school was opened in Paris in 1857 and started training in 1858-1859 in order to meet the need for qualified officers required for other military schools as well as the military and general culture courses taught at Mekteb-i Harbiye (War Academy) (Şişman, 2004: 41-42). This school, which was initially opened as a department in Mekteb-i Harbiye (War Academy), later served all students who went abroad for education in order to meet the needs of Engineering Schools, Medical School and other institutions (Unat, 1964: 66; Mehmet Esat, 1912: 67-68). This school prepared the students who were sent to Europe for education in different fields by the Ottoman Empire, remained uncontrolled and could not get enough efficiency, and who were not accepted to the Military Education institutions there due to the insufficiency of their education levels. Also, it prevented students from distancing to their own culture by keeping them together, while getting more efficiency at a more economical cost. Later, this school that made a name for itself as "Mekteb-i Osmani" (Ottoman School) played an important role in training the staff that left a mark on Turkey's education, science, culture and political life, while transferring the developments occurring in all fields in Europe. When they returned to Istanbul, their professional life got started from working as a teacher or manager in newly opened educational institutions, and sometimes even extended to the grand viziership. Many of them contributed to the preparation and management of important reform initiatives in different fields required by the empire, and became planners and executives. The most important contribution of these staff was that they had pioneered the transfer and development of modern sciences and institutions related to their education, educational curriculums, textbooks, teaching methods, and teaching materials. Undoubtedly, they undertook the same mission in terms of history and history education. These young staff, who were trained to serve in the Ottoman military and civil bureaucracy, pioneered modernization, and served with the awareness and responsibility of having received history education. With the consciousness that history education provided them, they grasped the benefits and value of history education, and recognized that history is an important component of contemporary education systems, and experienced that it should be given as a comprehensive course in schools at all levels, and provided significant support to facilitate its inclusion in the curriculum.

In "Mekteb-i Osmânî" (Ottoman School in Paris), students were divided into two and then three branches according to their levels (the best students were planned to be educated in the 1st branch, the students with disabilities in the 2nd branch, and the weak students in the 3rd branch). History was also placed among the lessons in the curriculum of Mekteb-i Osmânî (Ottoman School). In the school's 1859 curriculum, only the first 
branch had History and Geography courses together two hours of a week, then these two courses were separated from each other in the 1860 course schedule. It was placed in the first and second branches as a separate lesson for two hours on Mondays and Fridays, and as an hour per week on Mondays, Tuesdays, Fridays and Saturdays in the 1862 course schedule. The history lesson was given sometimes seperate, sometimes along with geography lesson (Şişman, 2004: 61-64).

In the curriculum of Mekteb-i Osmânî (Ottoman School), the history lesson took place under two separate sections as "Târîh-i Umûmî" (World History) and "Târîhi-i Husûsî" (National History). All the lecturers of Mekteb-i Osmânî (Ottoman School) were selected among people who stood out with their understanding and publications in the Paris Darülfünun. One of them was the history teacher Mr. Fikon. Since his political stance resembled the politics of the French, he was named Galya, the old name of the French. The late Governor of Bursa, Ahmet Vefik Pasha studied history, Latin and French lessons with him (at Saint Louis High School in Paris, where Ahmet Vefik Pasha graduated in 1834) (Mehmet Esat, 1911: 67).

According to Adnan Şişman, Edouard le Barbier prepared the curriculum of 1859. The history from the foundation of the Ottoman Empire to the conquest of Bursa was taught in this curriculum. Apart from this, the teacher also conveyed his views on these history lessons. 18th and 19th century history of other countries of Europe was added to the curriculum in 1860. The curriculum of 1862-1863 was prepared by Pavet de Courtrille. Pavet prepared a more detailed three-year curriculum. According to the curriculum, Eastern and Greek history was planned to be given in the first semester of the first year, Roman history in the second semester, the period from the 1st century to the end of the Charlemagne period in the first semester of the second year, the period from the 9th century to the capture of Istanbul by the Turks in 1453 in the second semester, and new age history lessons since the French Emperor Louis XI until the War of Whaterlo in the third year (Şişman, 2004: 41-42).

"Târîh-i Umûmî" (World History) and "Târîhi-i Husûsî" (National History) courses in Mekteb-i Osmânî (Ottoman School) had a noteworthy impact in the future of Turkey in terms of history education. Students who had their education in Mekteb-i Osmânî (Ottoman School) for years and took charge in military and civil bureaucracy when they returned to Turkey, played a key role in the introduction of curriculums in Turkey to history lessons. Military and civilian students had the opportunity to follow the developments in the field of history in France, as they took history lessons here. They returned to Turkey with historical consciousness, so they facilitated the history lessons take place in the curriculum. One of these students who returned to the country after receiving education in Europe, Selim Sabit Efendi wrote "Muhtasar Târîh-i Osmânî" (Brief History of Ottoman), the first history textbook written for primary schools. He also wrote a book titled "Rehnûmay-1 Muallimin" (Instructives for Teachers) briefly touches upon the purpose of history lessons and teaching methods, along with many lessons. Then, he became the person who determined the purpose, content and method of history education at primary school grade. Ahmet Vefik attended history classes at Mekteb-i Mülkiye (School of the Civil Services) for a period of time. He had a significant impact on history education and historiography by writing many historical books such as Salnâme-i Devlet-i Osmânî (1847), "Hikmet-i Târîh" (Philosophy of History) (1863), Fezleke-i Târîh-i Osmânî (1869) and more other stuff including copyrights and translations. Many names came after these two names as historians, who returned after having education in Europe to teach history in different military or civilian educational institutions in the following years.

\section{History Lessons in Mekteb-i T1bbiye-i Şahane}

"Mekteb-i Trbbiye-i Şahane" (Imperial School of Medicine) was the first school to teach "Tarih-i Osmânîye" (Ottoman History) and "Tarih-i Umûmî" (World History) courses not just for military purposes in the Ottoman Empire. 
Table 3. Introduction of the curriculum in Mekteb-i Tibbîye to history lessons

\begin{tabular}{lll}
\hline Course & Class & Starting Date \\
\hline Ottoman History & Preparatory Class 3 ${ }^{\text {rd }}$ Year & $1841-1842$ \\
World History & Preparatory Class 3 3 & $1842-1843$ \\
\hline
\end{tabular}

There was no history lesson in the first curriculums of the "Tibhane-i Âmire" (Mandatory Medical School) and "Cerrahhane-i Mâmûre" (School of Medicine and Urban Surgery), which started training on March 14, 1827 to meet the needs of the Ottoman Army for physicians and surgeons. Even though the geography lesson was included to the curriculum of Tibbiye (Medical School) with the regulation made in 1839, the first history lessons was taught in the 1841-1842 Academic Year according to the Activity Report. Teacher Doe taught History of the Ottoman State along with French, Geography, Geometry, Animal Science in the third year's curriculum (Ülman, 2017: 198), and Mr. Rouet was assigned for the same courses in 1842-43 (Ülman, 2017: 210). Mr. Guerieri gave "Devlet-i Osmânîye Tarihi" (History of Ottoman State) courses to the second grades in 1843-44, while M.S. Rouet gave "Tarih-i Umûmî" (World History) courses to the third grades (Ulman, 2017: 220). In the following years, the duration of the introductory classes was increased in order to prepare the students for medical education. The first graders took "Devlet-i Osmânîye Tarihi" (History of Ottoman State) courses, and the second graders took "Tarih-i Umûmî" (World History) courses. In this period, since the education in Medical School was in French, history lessons were taught in French just like geography, algebra and geometry (Aslan, 2015: 391-394). It is noteworthy that the teachers who taught history were French or foreign professors who could speak French.

In El-Haj Riza Tahsin Efendi's book named Mirat-1 Mekteb-i Tibbiye (The Mirror of Medical School), he stated that apart from "Tarih-i Umûmî" (World History) course, philosophy course was also put in the curriculum of preparatory classes of medical education in "Mektebi Tibbiye-i Şahane" (Imperial School of Medicine) in 1861-1862. Mr. Gold, a British man who also spoke French, was assigned to teach "Tarih-i Umûmî" (World History) course. After a few years, Mr. Gold had gout. Aleksan Çaliki Efendi served as his substitute. He graduated ranking first in his class, came first in the test to become assistant teacher of internal diseases, and then got promoted to the rank of major. But the course was removed from the curriculum after a while because the expected efficiency could not be obtained (El-Haj Riza Tahsin, 1912: 49-50). It is known that Mr. Gold, who worked as a history teacher at Ecolé de Médicine, later served as an education inspector at "Mektebi Sultanî" (Galata Palace Imperial School) in 1868 (Şişman, 1989: 40). The fact that "Tarih-i Umûmî" (World History) was taught for the first time, albeit for a while, was very important and historical development in terms of history education. In the light of the available data so far, 1842 is the earliest date on which "Tarih-i Umûmî" (World History) courses were given. However, after the mid-1860s, the "Tarih-i Umûmî" (World History) and "Tarih-i Osmanî" (Ottoman History) courses were permanently included among the courses in junior high schools and at all levels of vocational schools. The first "Tarih-i Umûmî" (World History) courses, history teachers and history textbooks, albeit in French, entered the Ottoman education system at "Mektebi Trbbiye-i Şahane" (Imperial School of Medicine).

\section{History Textbooks of Military Schools}

Since the language of education in the early years of modern military schools was French, French history books were used in these schools. Although attempts were made to print Turkish history textbooks after the establishment of Encümen-i Daniş (Science Committee), it was not possible until the end of the 1860s. Depending on the increase number of modern educational institutions, commissions were formed and assignments were made to print the needed textbooks, especially for history lessons, "Tarih-i Umûmî" (World History) and "Tarih-i Osmânî" (History of Ottoman) textbooks (BOA İDH / 264-16459 - 05.03.1269). However, it was not possible to fulfill this demand until 1866-67. Although “Tarih-i Umûmî" (World History) lessons were included 
in the curriculum of military schools, there was no Turkish textbook that can be taught to students in the lessons. The first books written for history lessons included in the curriculums of modern schools of the period and published in Mekteb-i Harbiye's (War Academy) own printing house (Baysal, 2020: 259-278). The English translation of William Chambers' book by Ahmet Hilmi Efendi was the first important history book published in the Harbiye Printing House in 1866-67 for the history lessons given in Mekteb-i Harbiye's (War Academy). The book titled "Tarih-i Umûmî" (World History) was published in the Mekteb-i Harbiye (War Academy) Printing House in 1867-68. Ahmet Hilmi Efendi, from the Translation Chamber, was commissioned by the Ministry of Education to encounter the need for the "Tarih-i Umûmî" (World History) textbook for modern schools. As a result of his research, he decided to translate William Chambers's English book titled Universal History into Turkish as 12 volumes and completed the translation of the first volume in 1866. Ahmet Hilmi Efendi took an incentive fee and royalty for this translation (BAO A.MKT.MHM / 381-50 / H-05-01-1284). Although a "Tarih-i Umûmî" (World History) book was published in the Mekteb-i Harbiye (War Academy) in 1872, the Ministry of Education was asked not to publish the book without their approval because it was full of errors (BAO MF.MKT / 2-37, 24.04.1289).

The second important book written for Harbiye on the subject of Tarih-i Umûmî (World History:) is the book titled "Tarih-i Alem Kurun-1 Ula" (History of World: Antiquity) written by Süleyman Hüsnü Pasha and published in 1874. The most significant characteristic of the book is that it is the first book to include Turkish history comprehensively in the world history (Baysal, 2020: 259-278).

The first edition of "Fezleke-i Tarih-i Osmânî" (Summary of Ottoman History) written by Ahmet Vefik Pasha was published in Mekteb-i Harbiye Printing House in the same year. Both books were published to be used in the "Tarih-i Umûmî" (World History) and "Tarih-i Osmânî" (Ottoman History) courses in the curriculum of military and civilian schools. In the light of the accessible documents, it seems that those were the first books published in Turkish. Another important textbook was the work of Ömer Naili Bey, named "Fenn-i Harb ve Tarihi-i Askeri" (Science of War and Military History), published in Harbiye Printing House in 1867. The second chief work in this field was Mustafa Şevki Bey's book written for "Tarih-i Harb" (War History) lessons, which was also published in the same printing house in 1874. The first textbooks needed for history lessons were written for the Mekteb-i Harbiye (War Academy) and printed in the school's printing house till the end of the 1870s.

\section{Conclusion and Discussion}

The madrasahs, which were the traditional educational institutions of the Ottoman Empire, did not include history lessons in their curriculum. "Mühendishâne-i Bahri Humâyûn" (The Imperial School of Naval Engineering), "Mühendishâne-i Berrî-i Humâyûn" (The Imperial School of Military Engineering), "Mekteb-i Harbiye" (War Academy), "Mekteb-i Osmânî" (Ottoman School) and "Mekteb-i Tibbîye" (Medical School) were the first schools that taught history lessons. "Tevarih-i Harb" (War History) was the first history course taught in the educational institutions of the Ottoman Empire, in the curriculum of "Mühendishâne-i Berrî-i Humâyûn" (The Imperial School of Military Engineering). The inclusion of this course in the curriculum had purely for military purposes. "Devlet-i Osmânîyye Tarihi" (History of Ottoman State) and "Tarih-i Umûmî" (World History) were the first courses that were taught for a more general purpose, in French in "Mekteb-i Trbbîye" (Medical School). "Devlet-i Osmânîye Tarihi" (History of Ottoman State), which was one of the history courses not yet included in the curriculum of traditional educational institutions, was first taught in 1841-1842 and "Tarih-i Umûmî" (World History) in 1842-1843 with the "Mekteb-i Tibbîye" (Medical School) curriculum. The officers who returned to the country by receiving education in the "Mekteb-i Osmanî" (Ottoman School in Paris) and in different countries of Europe played an crucial role in the teaching of history lessons in the curriculum of modern military schools and in other civil schools in the Ottoman Empire. The fact that they returned to history lessons in a period when important developments were being experienced in the field of history 
education and historiography in Europe led to expectations in terms of the political and social cultures of the countries. So that, history lessons gained a great significance in the curriculum of modern schools. The interest and importance given to the history education in Europe created favorable conditions for the Ottoman Empire to develop its own modern schools. For this reason, after the 1850s, history education started to be included as a core course at the junior high levels of all modern schools opened for military and civilian purposes. Hence, history education took an important place in the curriculums of all schools providing education at all levels with "Maarif-i Umûmîye Nizamnâmesi" (Regulation of Public Education) in 1869. The first "Tarihi Osmânî" (Ottoman History), "Tarih-i Umûmî" (World History) and "Tarih-i Harb" (War History) textbooks were written for schools based on the history textbooks being taught in similar schools in Europe. The first history teachers and historians were the officers trained in these schools. However, towards the end of the 1880s, with Abdulhamid II 's regime of tyranny, history lessons were excluded from the curriculums and lost their importance.

This research was carried out in order to eliminate the limitations about the data on historical education in the Ottoman Empire regarding the period before "Maarif-i Umûmîye Nizamnâmesi" (Regulation of public Education). This paper reveals the place of history lessons before "Maarif-i Umûmîye Nizamnâmesi" (Regulation of Public Education). For this reason, it is recommended to conduct more in-depth research on the aforementioned textbooks to get complete information about the content of history education given in military schools and the understanding of history they represent. 


\section{REFERENCES}

Adıvar, A. (1991). Osmanlı Türkleri'nde ilim. İstanbul: Remzi Kitabevi.

Aslan, E. (2016). Geçmişten günümüze sosyal bilgiler. In D. Dilek, (Ed), Sosyal bilgiler eğitimi (pp. 3-48.). Ankara: Pegem Akademi.

Aslan, E. \& Akçiçek. E. (2015). Modern fen bilimlerinin Türkiye'ye girişinde tıbbiye'nin rolü ve ilk fen bilimciler. In E. Akçiçek \& F. Çakmak (Eds.). Vatan ve sıhhat: Tibbiyenin yurtseverliği. (pp.379-428). İzmir: Bulaşıcı Hastalıklar Derneği.

Ata, B. (2017). Tarih öğretiminin tarihi (1869-1922 dönemi). In İ.H. Demircioğlu \& E. Demircioğlu (Eds). Türkiye'de tarih eğitimi araştırmaları el kitabı. (pp.1-28). Ankara: Pegem Akademi,

Baysal, J. (2020). Osmanl Türklerinin bastıkları ilk kitaplar: Müteferrika'dan birinci meşrutiyete kadar 1729-1875 (kitapların tam listesi) (Prep. H. Keseroğlu, \&İ. Mengülerek). İstanbul: Hiper Yayın.

Baysun, C. (1997). Ahmed paşa (bonneval, humbaracıbaşı), In MEB İslam ansiklopedisi. (Vol. 1, pp.199). İstanbul.

Baysun, C. (1997). Kumbaracı. In MEB İslâm ansiklopedisi. (Vol. 6, pp. 982-985). İstanbul.

Berkes, N. (n.d.). Türkiye'de Çağdaşlaşma. İstanbul.

Beydilli, K. (1995). Türk bilim ve matbaacılı tarihinde mühendishane, mühendishane matbaası ve kütüphanesi. İstanbul: Eren Yayinevi.

BOA (Türkiye Cumhuriyeti Cumhurbaşkanlığı Devlet Arşivleri Başkanlığı Osmanlı Arşivi [Turkish State Archive]), (IDH/ 264-16459- 05.03.1269)

BOA (Türkiye Cumhuriyeti Cumhurbaşkanlığı Devlet Arşivleri Başkanlığı Osmanlı Arşivi [Turkish State Archive]), (A.MKT.MHM/381-50 / H-05-01-1284).

BOA (Türkiye Cumhuriyeti Cumhurbaşkanlığı Devlet Arşivleri Başkanlığı Osmanlı Arşivi [Turkish State Archive]), (MF.MKT/ 2-37, 24.04.1289).

Bülbül, D. V. (2019). Tarih eğitiminin Osmanl eğitim kurumlarına XIX Yüzyıldan itibaren girmesinin sebepleri. Unpublished master thesis, Gazi University, Graduate School of Educational Sciences, Ankara.

Cihan, A. (2007). Osmanlı'da eğitim. İstanbul: 3F Yayınevi.

Demircioğlu, İ. H. (2012). Osmanlı Devleti'nde tarih yazımının tarih öğretimi üzerine etkileri. Milli Eğitim, 193, 115-125.

Demircioğlu, İ H. (2008). Türkiye'de tarih eğitiminin tarih. Türkiye Araştırmaları Literatür Dergisi, 12, 431-450.

Demiryürek, M. (2003). Tanzimat'tan cumhuriyete bir Osmanlı aydını Abdurrahman Şeref Efendi 1853-1925. Ankara: Phoenix Yayınevi.

Dervişoğlu, F. M. (2015). Türk tarih düşüncesinin modernleşmesi. İstanbul: Ötüken Yayınları.

Dölen, E. (1985). Mühendislik eğitimi. Tanzimat'tan cumhuriyet'e Türkiye ansiklopedisi. (Vol. 1, pp. 511-516). İstanbul: İletişim Yayınları.

Dölen, E. (1985). Tanzimat'tan cumhuriyete bilim. Tanzimat'tan cumhuriyete Türkiye ansiklopedisi. (Vol. 1, pp. 134-196). İstanbul: İletişim Yayınları.

El-Hac Rıza Tahsin. (1991). Tıp fakültesi tarihçesi (Mir'ât-ı Mekteb-i Tibbiye): I-II, Kazancıgil, A. (Pub.), Özel Yayınlar. 
Erdem, S. (1986). Mirât-ı mühendishâne-i berrî hümaâyûn: İstanbul Teknik Üniversitesi tarihçesi. İstanbul: İ.T.Ü. Bilim ve Teknoloji Tarihi Araştırma Merkezi.

Erdoğan, A. (2016). Osmanlı'da yurt dışı eğitim ve modernleşme. İstanbul: Büyüyen Ay Yayınları.

Erendil, M. (1988). Topçuluk tarihi. Ankara: Genel Kurmay Basımevi.

Ergin, O. N. (1977). Türk maarif tarihi: İstanbul mektepleri ve ilim, san'at ve terbiye müesseseleri. İstanbul: Eser Matbaasi.

Ergun, M. \& Duman, M. (2014). 19. Yüzyılda Osmanlı askeri okullarının ders programları ve ders kitapları. Yeni Türkiye, 7, 494-511.

Erkan, S. (2017). Osmanlı döneminde tarih öğreniminin tarihçesi. 21. Yüzyılda Eğitim ve Toplum, 6(17), 394-424.

Gök, H. (2005). Arşiv belgelerinin ışı̆̆ında kara harp okulu tarihi (1834-1883). Unpublished master thesis, Hacettepe University, The Ataturk Institute for modern Turkish History, Ankara.

Gökçen, M. (2020), Osmanlı tarih algısının dönüşümünde Avrupa etkisi ve asr-ı hazır (çağdaş) Avrupa tarihçiliğinde üç isim: Abdurrahman Şeref, Diran Kelekyan, Yusuf Akçura. Unpublished master thesis, Dokuz Eylül University, Graduate School of Principles of Ataturk and Turkish Revolution, İzmir.

Kaçar, M. (1994). Osmanlı Devleti'nde mühendishanelerin kuruluşu ve bilim ve eğitim anlayışındaki değişmeler. Unpublished master thesis, İstanbul University, Graduate School of Social Sciences, İstanbul.

Kaçar, M. (1998). Osmanlı imparatorluğunda askeri teknik eğitimde modernleşme çalışmaları ve mühendishanelerin kuruluşu (1808'e kadar). Osmanlı Bilimi Araştırmları, 2, 69-137.

Kaçar, M. (1999). Osmanlı imparatorluğunda mühendishanelerin kuruluşu. In G. Eren (Ed.), Osmanlı VIII (pp. 680697). Ankara: Yeni Türkiye Yayınları.

Kafadar, O. (1997). Türk eğitim düşüncesinde batılllaşma. Ankara: Vadi Yayınları.

Karasar, N. (2007). Bilimsel araştırma yöntemi. Ankara: Nobel Yayın Dağıtım.

Kazancıgil, A. (2006). Osmanlılarda bilim ve teknoloji. İstanbul: Etkileşim Yayınları.

Koçer, H. A. (1991). Türkiye'de modern eğitimin doğuşu ve gelişimi (1773-1923). Ankara: Milli Eğitim Yayınları.

Kurtcephe, İ \& Balcıŏlu, M. (1991). Kara harp okulu tarihi. Ankara: Kara Harp Okulu Matbaası.

Mehmet Esat. (1310). Mirat-ı mekteb-i harbiye. İstanbul.

Nakıp, T. (2006). Osmanlı devleti'nde geç dönem tarih-i umumileri. Unpublished master thesis, Marmara University, Graduate School of Turkish Studies, İstanbul.

Özdemir, R. \& Aydın, A. (2019). Osmanlı tarih yazıcılığında muhtasar umumi tarihler üzerine. Anasay, 3(7), $105-136$

Özteke, F. (2006). XIX. yüzyılda Osmanlı Devleti'nde tarih eğitimi. Unpublished master thesis, Selçuk University, Graduate School of Social Sciences, Konya.

Sakaoğlu, N. (1991). Osmanlı Ĕ̆itim Tarihi. İstanbul: İletişim Yayınevi.

Şengül, T. (2006) Meşrutiyet'ten Cumhuriyet'e siyasi fikir akımlarının tarih eğitimine yansımalar (1908-1931). Unpublished master thesis, Çanakkale On Sekiz Mart University, Graduate School of Social Sciences, Çanakkale.

Şişman, A. (1989). Galatasaray Mektebi Sultânisi'nin kuruluşu. İstanbul: Edebiyat Fakültesi Yayınları. 
Şişman, A. (2004). Tanzimat Dönemi'nde Fransa'ya gönderilen Osmanlı öğrencileri (1839-1876). Ankara: Türk Tarih Kurumu Basımevi.

Toderini, G. (2018). Türkler'in yazll kültürü (Türkler'in edebiyatları). (Trans., A. Berktay). İstanbul: Yapı Kredi Yayınları.

Tuncay, T. (1977). Ilk ve ortaöğretimde tarih. Felsefe kurumu seminerleri. Ankara: Türk Tarih Kurumu Basımevi.

Türk, İ. C. (2013). Osmanlı Devleti'nde tarih eğitimi (1839-1922). İstanbul: Arı Sanat Yayınları,

Türkcan, E. (2009). Dünya'da ve Türkiye'de bilim teknoloji ve politika. İstanbul: Bilgi Üniversitesi Yayınları.

Uluçay, Ç. \& Kartekin, E. (1958). Yüksek mühendis okulu (yüksek mühendis ve yüksek mimar yetiştiren okulların tarihi). İstanbul: Berksoy Matbaası.

Unat, F. R. (1964). Türkiye eğitim sisteminin gelişmesine tarihi bir bakış. İstanbul: Milli Eğitim Yayınları.

Uzunçarşılı, İ. H. (1988-a. Osmanlı tarihi IV: I. bölüm: Karlofça anlaşmasından XVIII: yüzyılın sonlarına. Ankara: Türk Tarih Kurumu Basımevi.

Uzunçarşılı, İ. H. (1988b). Osmanlı Devleti teşkilatından kapukulu ocakları-2: Cebeci topçu, top arabacıları, humbaracı, lağımcı ocakları ve kapukulu süvarileri. Ankara: Türk Tarih Kurumu Basımevi.

Uzunçarşılı, İ. H. (1988c). Osmanlı Devleti'nin merkez ve bahriye teşkilatı. Ankara: Türk Tarih Kurumu Basımevi.

Ülman, Y. I. (2002). Mekteb-i tıbbiyenin 1850-51 öğretim yılı faaliyet raporu ve mezuniyet töreni. Osmanlı Bilimi Araştırmaları, 4(1), 57-64.

Yıldırım, A \& Şimşek, H. (2006). Nitel araştırma yöntemleri. Ankara: Seçkin Yayınevi.

Yıldız, R. (2006). I. Meşrutiyet döneminde uygulanan tarih eğitim. Unpublished master thesis, Selçuk University, Graduate School of Social Sciences, Konya. 